\title{
ON THE SEA-ICE REGIME OF THE ROSS SEA, ANTARCTICA
}

\author{
By ANDREW P. STURMAN* \\ (Department of Geography, University of Birmingham, Birmingham B15 2TT, England) \\ and MARK R. ANDERSON \\ (Cooperative Institute for Research in Environmental Sciences, \\ University of Colorado, Boulder, Colorado 80309, U.S.A.)
}

\begin{abstract}
A study is made of the sea-ice regime of the Ross Sea, Antarctica, using ESMR passive microwave data and supporting information. Inferences are made of the processes responsible for observed spatial and temporal seaice variations. Air flow appears to have a dominant influence on sea-ice distribution and movement, with oceanic circulation playing a more minor role. This is particularly so with coastal polynya development, where katabatic winds are important. It has been possible to identify broad areas of ice convergence and divergence by assimilating the rather limited oceanic and atmospheric information with observed sea-ice variations. In spite of some basic physical similarities of the Weddell and Ross Seas, it is apparent that the major differences in their sea-ice regimes are due to the differing roles of oceanic and atmospheric circulation in each area. The Antarctic Peninsula plays a key role in these differences. Suggestions for further research are also considered.
\end{abstract}

RÉsumé. Régime de la glace de mer dans la Ross Sea, Antarctique. On étudie le régime de la glace der mer dans la Ross Sea, à l'aide de données micro ondes passives (ESMR) et d'informations complémentaires; on en déduit les processus responsables des variations spatiotemporelles de la glace de mer. Le vent paraît avoir une influence dominante sur la répartition de la glace de mer et son mouvement, alors que la circulation océanique ne joue qu'un rôle mineur, notamment dans le développement des polynies cotières dans les régions où les vents catabatiques sont importants. Il a été possible d'identifier de vastes étendues de convergence et de divergence de glace en associant les rares informations océaniques et atmosphériques aux

\section{INTRODUCTION}

The Ross Sea is one of two major embayments around the edge of Antarctica (Fig. 1). As with the Weddell Sea, it represents a major incursion of the sea into the lower-elevation West Antarctica, but is bounded on the west by the higher mountains of Victoria Land on the edge of the Polar Plateau. These are part of the Transantarctic Mountains which transect the continent.

The Ross Ice shelf provides an abrupt coastline in the form of an ice cliff to the south, while the eastern side is less confined than that to the west. As with the Weddell Sea, the Ross Sea consists of relatively cold water which experiences a cyclonic circulation. It is not surprising that these two areas also experience the coldest coastal temperatures of the Antarctic (Zwally and others, 1983).

*On leave from University of Canterbury, Christchurch, New Zealand. variations observées de la glace de mer. Malgré certaines similitudes physiques entre le Weddell Sea et Ross Sea, il apparaît que les différences majeures dans leurs régimes de glace de mer sont dues aux rôles différents des circulations océaniques et atmosphériques dans ces deux régions. La Antarctic Peninsula joue un rôle clef dans ces différences. On présente aussi des suggestions pour de futures recherches.

Zusammenfassung. Über das Verhalten des Meereises in der Ross-See, Antarktika. Mit Hilfe von Daten des passiven ESMR-Mikrowellensystems und zusätzlichen Informationen wurde das Verhalten des Meereises in der Ross-See, Antarktika, untersucht. Für die Prozesse, die für die beobachteten räumlichen und zeitlichen Veränderungen des Meereises verantwortlich sind, werden Folgerungen hergeleitet. Die Strömung der Luft scheint einen beherrschenden Einfluss auf die Verteilung und Bewegung des Meereises zu haben, wăhrend ozeanische Strömungen eine untergeordnete Rolle spielen. Dies gilt vor allem für die Entwicklung der Küsten-Polynien, wo katabatische Winde von Bedeutung sind. Durch Vergleich der eher spärlichen ozeanischen und atmosphärischen Informationen mit beobachteten Meereisverănderungen war es möglich, weite Gebiete mit Eiskonvergenz bzw. -divergenz zu erkennen. Trotz einiger grundsătzlicher physikalischer Ähnlichkeiten zwischen der Weddell- und der Ross-See ergeben sich offensichtlich die grösseren Unterschiede im Verhalten ihres Meereises aus der verschiedenen Bedeutung der ozeanischen und atmosphărischen Zirkulation im jeweiligen Gebiet. Die Antarctic Peninsula spielt dabei eine Schlüsselrolle. Vorschläge für weitere Untersuchungen werden vorgelegt.

In spite of these similarities, there are distinct differences in the sea-ice regime of the two areas. The polynya which forms in the eastern Weddell Sea is quite distinctive, as is the major area of pack ice which persists through the summer along its western side (Ackley, 1981). The reasons for these general differences in sea-ice concentrations are not yet known, as the mechanisms of the seasonal expansion and decay of Antarctic sea ice are only poorly understood (Barry, 1983). The major aim of this paper is therefore to examine the sea-ice regime of the Ross Sea using ESMR (Electrically Scanning Microwave Radiometer) data, and by reviewing recent literature, to develop hypotheses about the principal mechanisms involved. Such hypotheses are developed on the basis of observed seasonal sea-ice variations and the small amount of supplementary data available, as well as the results of previous research. The supplementary data provide only a superficial view of atmospheric and oceanic conditions. Previous research on sea ice is also limited, with ideas of ice drift dependent largely on the track of Aurora which was trapped in the ice around the turn of the century (Wordie, 1921; Ackley, 


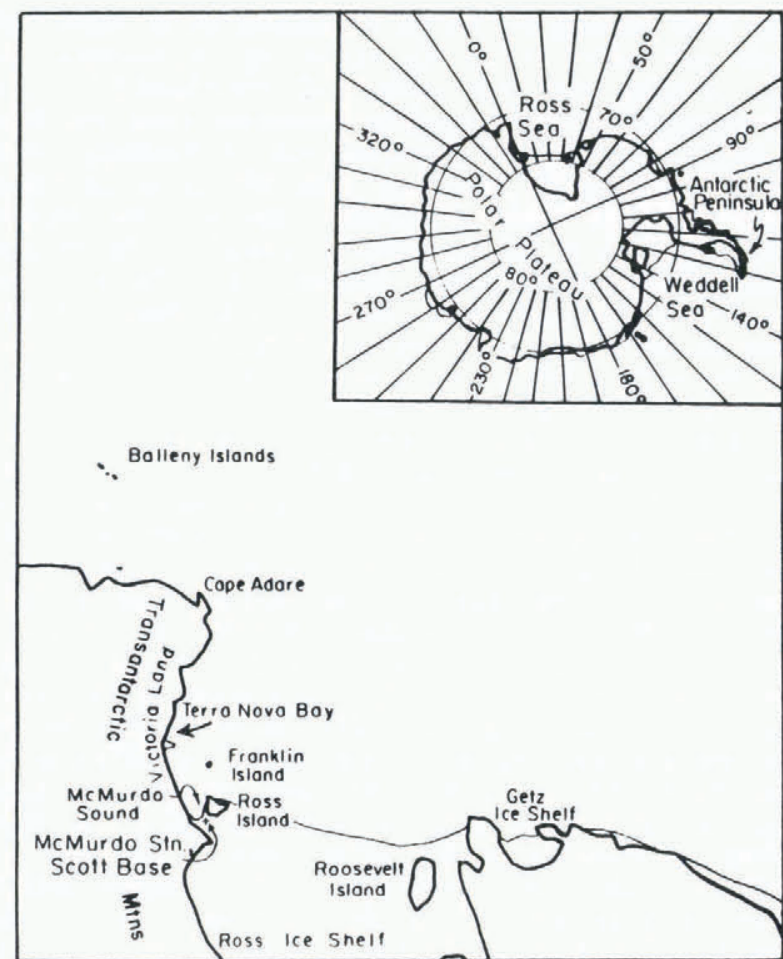

Fig. 1. Physical features of the Ross Sea area.

1981). It is hoped, however, that the hypotheses developed here can be tested over the next few years as the Ross Sea AWS (Automatic Weather Station) network expands (personal communication from C. Stearns) and field data collection on sea ice increases.

\section{SEA-ICE PROCESSES AND DATA}

Antarctic sea ice contrasts markedly with that of the Arctic largely because it is not confined by continental land masses but is totally surrounded by ocean (Ackley, 1981; Andreas and Ackley, 1982). The Antarctic sea ice experiences a much greater annual variation in extent (Ackley and Keliher, 1976) which has meant an annual turn-over of ice. As a result, almost all of the pack is "first-year" ice (Ackley, 1981). Although most of the research on ice processes has concentrated on the Weddell Sea, it seems that the same general ideas of ice type and development also apply to the Ross Sea. In particular, advection (due to winds and currents) plays an important part in the growth of sea ice, particularly from March to June (Ackley, 1981). However, Carleton (1981) has suggested that movement and distribution of the Ross Sea pack ice is influenced more by cyclonic weather systems, while the Weddell Sea pack ice is dominated by the oceanic gyre. In a limited study, De Rycke (1973) suggested that the general movement off the Getz Ice Shelf (Fig. 1) is due to ocean currents while air flow causes short-term variability.

Expansion of the pack ice occurs through the combined effect of low temperatures and offshore movement of ice (whether by air flow or ocean currents). Ice formed near the coast is advected northward leaving more open water to be frozen (Ackley, 1981; Hibler and Ackley, 1983). Further growth of the pack ice may also be due to the continual development of open water by Ekman divergence of surface water and sea ice due to wind stress (Gordon and Taylor, 1975). This open water within the pack ice freezes and the total ice area expands. In spring and summer the open water acts in absorbing solar radiation which subsequently assists in melting the ice. The outer ice edge, however, is determined by the balance between supply of sea ice by advection and melting due to higher air or sea temperatures. Consequently, where the ice edge appears stationary over several weeks, the melt rate is equal to sea-ice advection.

Clearly, both these dynamic and thermal influences on the sea-ice regime are closely related to synoptic scale atmospheric circulation. Local air flow is also influenced by the strong katabatic outflow from the Antarctic continent (Parish, 1982) but this too is modified by synoptic disturbances. The impact of strong katabatic outflow from the Polar Plateau in developing the Terra Nova Bay polynya appears to be greater than originally thought possible (Kurtz and Bromwich, 1983). However, this may be due to synoptic reinforcement of the drainage wind. Oceanic circulation also has a two-way relationship with the atmosphere. It has been suggested that ice transport from the Weddell Sea strongly influences mid-latitude temperature and presumably atmospheric circulation in the South Atlantic region (Schwerdtfeger, 1979). The location of cyclogenetic zones also appears to be determined by the sea-ice edge (Carleton, 1981, 1983). The complex relationship between synoptic circulation, oceanic circulation, katabatic winds, and sea ice is still largely unknown. However, it is clear that the strength and tracking of cyclonic disturbances have a major impact on sea-ice concentrations and movement (Schwerdtfeger and Kachelhoffer, 1973; Carleton, 1981, 1983). Consequently, the year-to-year variability of sea-ice cover is largely a function of such synoptic scale characteristics, and these in turn are influenced by global circulation variations. The current lack of knowledge of the relationships between Antarctic sea ice and atmospheric circulation at all scales is a major cause for concern (Budd, 1982). Global climate modelling, for example, relies on an accurate parameterization of these relationships (Bennett, 1982).

Study of the sea-ice regime of the Ross Sea requires repetitive observations of the whole area at adequate resolution. These observations should cover the complete annual cycle including the polar night period. Passive microwave data are the most suitable because of their all-weather all-year capabilities. Such data are available for 1973-76 from the ESMR sensor on board the Nimbus 5 satellite, at a resolution of $30 \mathrm{~km} \times 30 \mathrm{~km}$. This radiometer recorded brightness temperatures at the $1.55 \mathrm{~cm}$ wavelength (Zwally and others, 1983). Although the relationship between sea-ice concentrations and brightness temperatures is complicated by varying surface characteristics of sea ice, there is a roughly linear correspondence. However, the resulting inaccuracies and limited resolution restrict the use of these data to study of regional rather than local ice conditions. The more sophisticated SMMR (Scanning Multichannel Microwave Radiometer) has a five-channel, dual-polarizing sensor system but data sets for 1979 and 1980 are only now becoming available to the research community. The U.S. Navy-NOAA JIC (Joint Ice Centre) sea-ice charts for the Antarctic are based on visual and infra-red data from NOAA and DMSP (Defense Meteorological Satellite Program) satellites as well as the microwave systems. However, as they are largely concerned with delimiting large areas of roughly similar ice concentrations, their coarse resolution is limiting. They also provide winter-time estimates of the area of open water that are too low (Comiso and Zwally, 1982). This seems to be due to the fact that ice-surface temperatures are not taken into account in interpreting ESMR images. Also, open water in leads and polynyi smaller than about $1 \mathrm{~km}$ resolution in visual and infra-red images cannot be included accurately in estimates of ice concentration (Zwally and others, 1983). However, it can also be said that the digital ESMR data may overestimate the area of open water because of uncertainty as to the microwave emissivity of very thin ice under about $5 \mathrm{~cm}$ thick (Zwally and others, 1983). Following consideration of these problems, it was decided to base this study on the 1973-76 ESMR data. However, future work will incorporate the SMMR data as they become available.

\section{OCEANOGRAPHIC AND METEOROLOGICAL PROCESSES} IN THE ROSS SEA

Knowledge of oceanographic and meteorological processes in the Ross Sea area is limited. This is largely due to the inhospitable conditions for both personnel and equipment. However, in spite of the continued annual movement of people and supplies though the area, the data base is much less than that for the Weddell Sea. This lack 
of data is clearly evident in the writings of other researchers. The prime example is the use of the track of Aurora, which was trapped in the ice between 1915 and 1916, to indicate ice drift (e.g. Ackley, 1981). Only De Rycke (1973) has used satellite imagery to determine ice movement and that study was both temporally and spatially limited. Perchal's (1975) ice-forecasting guide for the western Ross Sea and McMurdo Sound is similarly tentative in describing surface air flow and currents in the Ross Sea area. Data bases, such as that of Jenne and others (1974), are based more on educated speculation than concrete observations as far as the Ross Sea area is concerned. Several oceanographic studies have been made but they have been largely concerned with describing and classifying sub-surface water masses using limited period survey data (e.g. Jacobs and others, 1970; Jacobs and Haines, 1982). Because of severe environmental conditions, it has not been possible to obtain the appropriate data, particularly in winter. However, the deployment of buoys would provide a useful data source, as would further extension of the AWS network to cover the coastline and of fshore islands of the Ross Sea. The network of AWS centred on McMurdo Station since $1979 / 80$ has become an increasingly important data source, as it has extended to other parts of the Ross Sea area (including the Ross Ice Shelf and Franklin Island) (see Fig. 1). The period of observation of available data is still very short. It is hoped that, as both the SMMR and AWS data become available over the next few years, the conclusions of the present study can be further examined.

On a very local scale, study of the Terra Nova Bay polynya has provided some idea of sea-ice processes around the edge of the Ross Sea (Kurtz and Bromwich, 1983; Bromwich and Kurtz, 1984) (Fig. 1). Several of their conclusions were based largely on conjecture and require further analysis before they can be confirmed. It appears that katabatic flow is frequently concentrated down glaciated valleys and may be a controlling factor in the development of coastal polynyi.

\section{SEASONAL VARIATIONS OF SEA ICE}

As already mentioned, the extent and distribution of sea ice in the Ross Sea is the result of a complex energy balance involving a range of factors including radiation fluxes, air temperature, sea temperature, wind stress, and ocean salinity. These are controlled by broader atmospheric and oceanic circulation features which cause upwelling, ice break-up, and advection. It is interesting, given their broad similarity in physical character and the dominant role of advection in both sea-ice regimes (Ackley, 1981), that the Ross Sea ice distribution varies distinctly from that of the Weddell Sea. The differences are said to be due to the greater role of oceanic circulation in the Weddell Sea and the deflecting effect of the Antarctic Peninsula (Fig. 1), while the Ross Sea is said to be influenced more by cyclonic weather systems (Carleton, 1981).

The seasonal variation of sea ice is illustrated in Figure 2. The major features are, first, a south-east to north-west axis of higher concentrations, and secondly a north to south zone of lower concentrations extending from the Ross Ice Shelf into and across the axis of higher concentrations. Along this zone, ice decay extends from the south in spring and lower concentrations persist throughout the year. Bearing in mind that sea-ice concentrations in any area are a function of formation, decay, and advection of ice, and that the prevailing winds are south-easterlies, it appears that sea ice moves generally along the south-east to north-west axis. This is supported by earlier ice-drift evidence discussed by Ackley (1981) and satellite observations of De Rycke (1973). It appears that differing rates of ice formation, advection, and decay produce convergence and divergence zones along this axis. For example, the eastern side of the Ross Sea consistently experiences higher concentrations, presumably receiving new supplies of ice from the east faster than it is removed or melted (i.e. ice convergence). The central and southern Ross Sea has lower ice concentrations at all times, suggesting that this is a zone of ice melting or divergence (Fig. 2). Potential causes are either stronger southerly winds moving the sea ice out of the area or upwelling of warmer or more saline water melting the ice (or a combination of these two) (Jacobs and others, 1970). By examining the succession of maps covering the melt period (October-January), it is apparent that this zone develops northward from the Ross Ice Shelf, suggesting the dominant role of southerly winds (Zwally and others, 1983). An area of ice accumulation appears to occur north of Victoria Land near the Balleny Islands (see Figs 1 and 2), which is thought to be an area of convergence (Streten, 1973; Ackley, 1981). The mean air flow, based on Jenne and others' (1974) data, indicates strong southerly and south-westerly winds over the western Ross Sea with a marked reduction in velocity between the Ross Sea and the Balleny Islands area.

More minor features of the sea-ice regime include the small-scale variability of concentrations around the coastline. In interpreting these features, the coarse resolution of the data and geographical complexity of the coast should be considered. The brightness temperatures used to derive concentrations in some cases will be derived from surfaces other than sea ice, including land, ice shelf, and multi-year ice. However, it is apparent from the trend of sea-ice concentrations within a few hundred kilometres of the coast that a lot of these zones of lower concentration along the coast are real and represent leads created by offshore air flow. It is also apparent that some sections of coast experience higher concentrations than others (Fig. 2). These include the coastline at the eastern end of the Ross Ice Shelf front and to the west of Cape Adare. Another area of interest is along the coast in the south-east corner of the study area illustrated in Figure 1. Here, there is a clear seasonal variation in the sea-ice concentrations, with very high concentrations in winter (April-October) but with development of two distinct polynyi in summer. These latter are probably due to localized katabatic outflow. A similar change occurs off the Ross Ice Shelf north of Roosevelt Island (see Fig. 1), where a polynya develops from November to December before merging with the more extensive open-sea area in January and February (Fig. 2). This feature is also probably due to the channelling of strong katabatic flow from the Ross Ice Shelf. Ice concentrations along the western coast of the Ross Sea show much local variation, including the McMurdo Sound and Terra Nova Bay polynyi (Stonehouse, 1967; Kurtz and Bromwich, 1983; Bromwich and Kurtz, 1984). The Terra Nova Bay polynya shows up quite clearly throughout the year, although the coast immediately to the north experiences persistently higher ice concentrations (Fig. 2). A band of higher concentrations also exists $100-200 \mathrm{~km}$ offshore and parallel to the coast during the winter months May-October (Fig. 2). It is likely that these features are strongly influenced by the interaction of regional katabatic and synoptic air flow. The convergence of south-easterly synoptic flow with the westerly katabatic winds along the coast could well contribute to a sea-ice accumulation zone offshore. As suggested by Kurtz and Bromwich (1983), cyclonic weather systems tracking through the Ross Sea area appear on occasions to enhance the strong katabatic flow so that offshore movement of sea ice is greater than that expected from katabatic flow alone. However, the modelling experiments by Parish (1982) suggest that katabatic outflow would be concentrated locally due to channelling by the topography and particularly down Reeves Glacier in Terra Nova Bay. This explains the variability observed along the coastline.

Another minor feature which provides some insight into regional sea-ice processes is the irregular advance of the ice edge between summer and winter. The monthly average sequence of maps from February to June shows the development of a bulge in the ice edge which grows northeastward over this period (Fig. 2). It would seem that this development relates first to the temperature gradient but, secondly, to the cyclonic movement of ice in the Ross Sea. Figure 3 provides a generalized view of sea-ice movement in the Ross Sea on the basis of the information and ideas discussed in this paper. The monthly development of the bulge in the sea-ice front is indicated by the open circles. This generalized view would, of course, vary seasonally in response to dynamic and thermodynamic factors.

The sea-ice circulation pattern of the Ross Sea differs from that of the Weddell Sea (Ackley, 1981) largely due to 


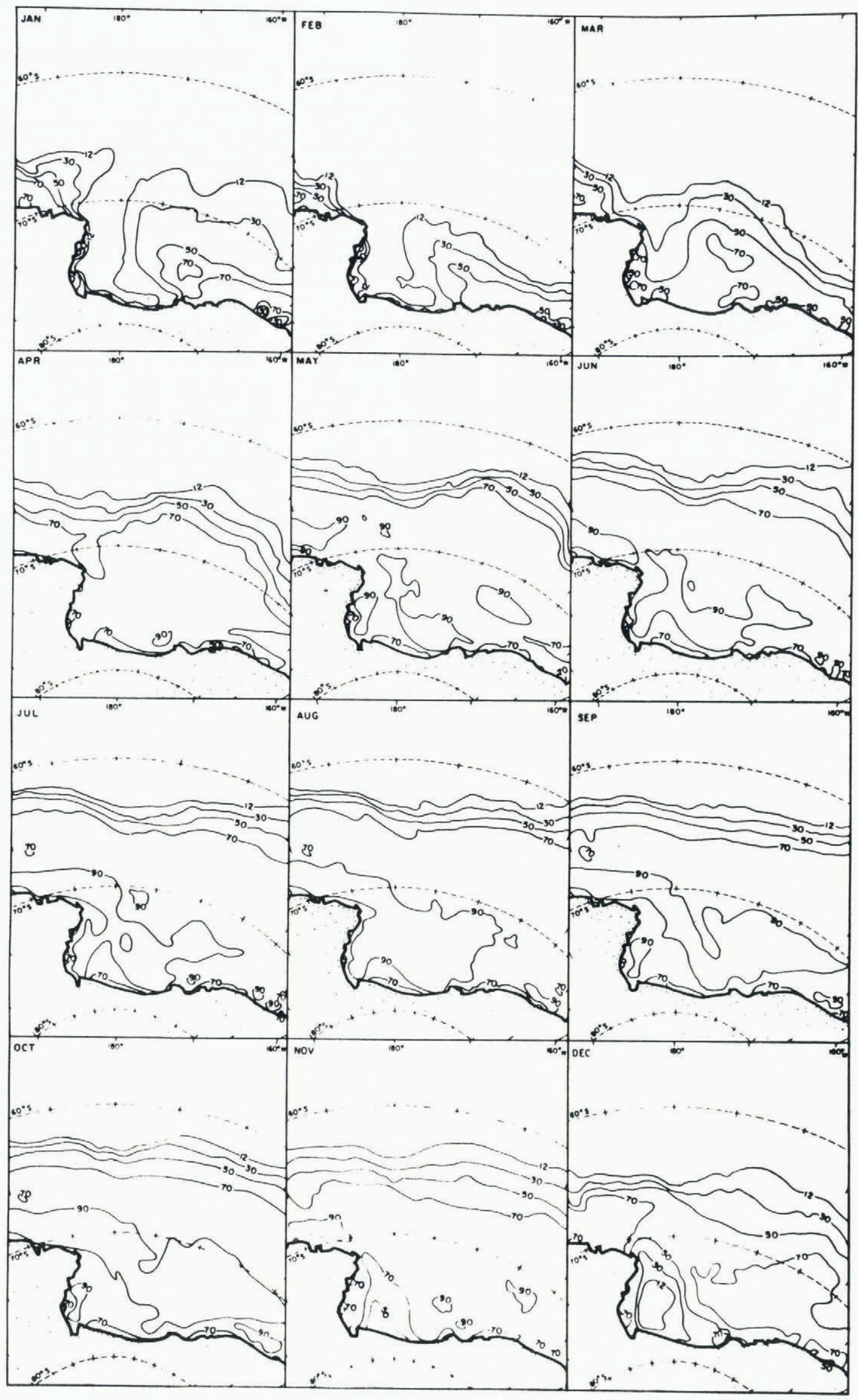

Fig. 2. Average monthly percentage concentrations of sea ice in the Ross Sea based on ESMR digital data. 


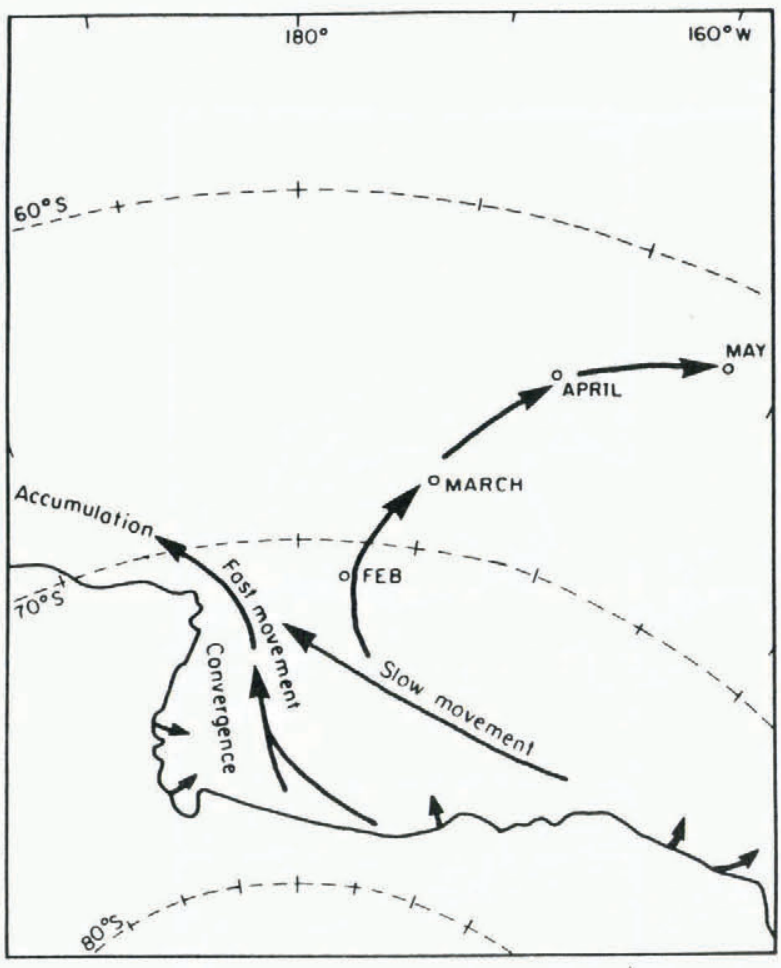

Fig. 3. Generalized pattern of sea-ice movement in the Ross Sea. The open circles represent the most northerly point on the ice edge in the months given.

the Antarctic Peninsula, which helps to trap sea ice on its eastern side, as well as causing it to move more strongly to the north-east. In contrast, at about lat. $70^{\circ} \mathrm{S}$. there is a region of divergence at the entrance to the Ross Sea (Fig. $3)$. The polynya of the eastern Weddell Sea is not duplicated in the Ross Sea, probably due to oceanographic differences between the two. This polynya is thought to be due to upwelling and subsequent basal melting ( $\mathrm{Z}$ wally and others, 1983, p. 121). It is also apparent from the persistent ice cover in the eastern Ross Sea that sea ice continues to be produced further to the east during summer. This contrasts markedly with the Weddell Sea as there is no significant source of sea ice for almost $80^{\circ}$ of longitude to the east in summer (see Zwally and others, 1983, p. 75). This presumably relates to different thermal conditions of both air and sea in these source areas.

\section{SUMMARY AND CONCLUSION}

This is the first study to deal specifically and in detail with the sea-ice regime of the Ross Sea. Until recently, there has been too little information to allow such a paper. Even now, it is only possible to provide a general overview to be used as the basis for future research. It is clear that much more analysis is required both of satellite-derived data and information collected in the field.

The information so far available provides a good indication of the nature of the sea-ice regime and the influence of dynamic and thermodynamic processes. After the Weddell Sea, this area experiences the greatest seasonal change in sea-ice concentrations in the Antarctic and is therefore of major climatic significance. In spite of some physical similarities, there are major differences in the distribution of sea ice in the two major embayments. Regional air flow seems to be the major control of the Ross Sea regime. Offshore winds play an important role in the formation and movement of ice through the Ross Sea, except north of about lat. $68^{\circ}$ to $70^{\circ} \mathrm{S}$., where the strong mid-latitude westerly winds become increasingly important. Along the coast, marked variability of sea-ice concentrations is due to topographic channelling of katabatic winds from the interior of the continent. Glaciated valleys are particularly important in generating strong outflow at the coast which helps to move sea ice offshore. This of fshore flow also appears to have a more general effect in providing a zone of lower ice concentrations around the coastline. In particular, offshore flow along the west coast and southerlies off the Ross Ice Shelf appear to produce a convergence zone further offshore in the western Ross Sea parallel to the coast.

A zone of lower ice concentrations trending north to south in the central Ross Sea is due to the strong southerly air flow, causing greater ice advection here. The eastern Ross Sea and near the Balleny Islands experience higher ice concentrations probably due to slower ice movement, convergence, and accumulation in these areas.

It is apparent that both dynamic and thermodynamic processes are important in the sea-ice regime. It seems that oceanographic factors are of lesser importance than atmospheric ones in determining ice distribution and concentration in the Ross Sea. However, Jacobs and others (1970) suggested that upwelling of circum-polar deep water in the southern Ross Sea assists in the first opening up of pack ice in spring.

It is clear that, although suitable sea-ice data are becoming increasingly available, further understanding of sea-ice processes in the Ross Sea requires much more atmospheric and oceanic data. The forcing fields to be measured include ocean currents and temperatures, wind, and air temperatures, as well as sea-ice characteristics (both structural and radiational). These measurements would require a co-ordinated programme involving ocean buoys, automatic weather stations, and field-data collection supported by satellite systems. This would provide information on sea-ice formation, movement, and decay, as well as the forcing functions responsible. It is hoped that such a programme could be executed in the next few years.

\section{ACKNOWLEDGEMENTS}

This work was partially supported by a National Science Foundation grant (DPP-817265) to Dr R. Barry, CIRES (Cooperative Institute for Research in Environmental Sciences), University of Colorado. We are also grateful to CIRES for their financial and technical support. Thanks are also due to Drs R. Barry, U. Radok, and R. Crane for their critical reviews of the manuscript. Dr Sturman would also like to thank the Department of Geography, University of Birmingham, for their generous support.

\section{REFERENCES}

Ackley, S.F. 1981. A review of sea-ice weather relationships in the southern hemisphere. [Union Géodésique et Géophysique Internationale. Association Internationale des Sciences Hydrologiques.] Sea level, ice, and climatic change. Proceedings of the symposium held 7-8 December 1979 during the 17th general assembly of the International Union of Geodesy and Geophysics, Canberra, p. 127-59. (IAHS Publication No. 131.)

Ackley, S.F., and Keliher, T.E. 1976. Antarctic sea ice dynamics and its possible climatic effects. AIDJEX Bulletin, Vol. 33, p. 53-76.

Andreas, E.L., and Ackley, S.F. 1982. On the differences in ablation seasons of Arctic and Antarctic sea ice. Journal of the Atmospheric Sciences, Vol. 39, No. 2, p. 440-47.

Barry, R.G. 1983. Research on snow and ice. Reviews of Geophysics and Space Physics, Vol. 21, No. 3, p. 765-76.

Bennett, T.J., jr. 1982. A coupled atmosphere-sea ice model study of the role of sea ice in climatic predictability. Journal of the Atmospheric Sciences, Vol. 39, No. 7, p. 1456-65.

Bromwich, D.H., and Kurtz, D.D. 1984. Katabatic wind forcing of the Terra Nova Bay polynya. Journal of Geophysical Research, Vol. 89, No. C3, p. 3561-72.

Budd, W.F. 1982. The role of Antarctica in southern hemisphere weather and climate. Australian Meteorological Magazine, Vol. 30, No. 4, p. 265-72.

Carleton, A.M. 1981. Ice-ocean-atmosphere interactions at high southern latitudes in winter from satellite observation. Australian Meteorological Magazine, Vol. 29, p. 183-95. 
Carleton, A.M. 1983. Variations in Antarctic sea ice conditions and relationships with southern hemisphere cyclonic activity, winters 1973-77. Archives for Meteorology, Geophysics and Bioclimatology, Ser. B, Vol. 32 , No. 1 , p. 1-22.

Comiso, J.C., and Zwally, H.J. 1982. Antarctic sea ice concentrations inferred from Nimbus 5 ESMR and Landsat imagery. Journal of Geophysical Research, Vol. 87, No. C8, p. $5836-44$

DeRycke, R.J. 1973. Sea ice motions off Antarctica in the vicinity of the eastern Ross Sea as observed by satellite. Journal of Geophysical Research, Vol. 78, No. 36, p. $8873-79$.

Gordon, A.L., and Taylor, H.W. 1975. Seasonal change of Antarctic sea ice cover. Science, Vol. 187, No. 4174, p. 346-47.

Hibler, W.D., III, and Ackley, S.F. 1983. Numerical simulation of the Weddell Sea pack ice. Journal of Geophysical Research, Vol. 88, No. C5, p. 2873-87.

Jacobs, S.S., and Haines, W.E. 1982. Oceanographic data in the Ross Sea and along George V Coast, 1976-1979. Palisades, NY, Lamont-Doherty Geological Observatory of Columbia University. (Ross Ice Shelf Project. Technical Report LDGO-82-1.)

Jacobs, S.S., and others. 1970. Ross Sea oceanography and Antarctic bottom water formation, by S.S. Jacobs, A.F. Amos, and P.M. Bruchhausen. Deep-Sea Research, Vol. 17 , No. 6 , p. $935-62$.

Jenne, R.L., and others. 1974. A selected climatology of the southern hemisphere: computer methods and data availability, by R.L. Jenne, H.L. Crutcher, H. van Loon, and J.J. Taljaard. Boulder, CO, National Center for Atmospheric Research. (NCAR-TN/STR-92.)
Kurtz, D.D., and Bromwich, D.H. 1983. Satellite observed behavior of the Terra Nova Bay polynya. Journal of Geophysical Research, Vol. 88, No. C14, p. 9717-22.

Parish, T.R. 1982. Surface airflow over East Antarctica. Monthly Weather Review, Vol. 110, No. 2, p. 84-90.

Perchal, R.J. 1975. Western Ross Sea and McMurdo Sound ice forecasting guide. Washington, DC, U.S. Naval Oceanographic Office. (Special Publication SP265.)

Schwerdtfeger, W. 1979. Meteorological aspects of the drift of ice from the Weddell Sea towards the mid-latitude westerlies. Journal of Geophysical Research, Vol. 84, No. C10, p. 6321-28.

Schwerdtfeger, W., and Kachelhoffer, S. 1973. The frequency of cyclonic vortices over the Southern Ocean in relation to the extension of the pack belt. Antarctic Journal of the United States, Vol. 8, No. 5, p. 234.

Stonehouse, B. 1967. Occurrence and effects of open water in McMurdo Sound, Antarctica, during winter and early spring. Polar Record, Vol. 13, No. 87, p. 775-78.

Streten, N.A. 1973. Satellite observations of the summer decay of the Antarctic sea-ice. Archiv für Meteorologie, Geophysik und Bioklimatologie, Ser. A, Bd. 22, Ht. 1, p. 119-34.

Wordie, J.M. 1921. The Ross Sea drift of the "Aurora" in 1915-1916. Geographical Journal, Vol. 58, No. 3, p. 219-24.

Zwally, H.J., and others. 1983. Antarctic sea ice, 1973-1976: satellite passive-microwave observations, by H.J. Zwally, J.C. Cosimo, C.L. Parkinson, W.J. Campbell, F.D. Carsey, and P. Gloersen. Washington, DC, National Aeronautics and Space Administration. (NASA SP-459.) 